\title{
The Role of Teachers in Developing Adolescent's Competitive Spirit
}

\author{
Ririanti Rachmayanie \\ Universitas Lambung Mangkurat \\ Banjarmasin, Indonesia \\ ririanti.bk@unlam.ac.id
}

\begin{abstract}
Education has a very important and strategic role in national development. Education is considered as a process of fostering and developing individual self-awareness, including in adolescents. Adolescents are considered as a generation that is constantly looking and ready to create something. Therefore, to maximize their potential, an attention for them is needed, especially in interacting. One real positive effort that can be done by teachers is building their competitive spirit through a varied sports activities. The competitive spirit is very important to develop by adolescents since it can teachers them to compete with sportsmanship, however, it is not easy to develop it. The identification of psychological factors can affect the development of competitive spirits in adolescents, therefore it needs to be studied in depth.
\end{abstract}

\section{Keywords-teacher, adolescent, competitive spirit}

\section{INTRODUCTION}

Indonesia's education world currently faces at least four major complex challenges. First, the challenge in increasing 'added value', which is dealing with how to increase the added value in order to increase productivity, growth, and equity of the economy, as an effort to maintain and improve the development of sustainable education.

Second, the challenge to conduct a comprehensive and indepth assessment of the transformation (transformation) of community structures, from agrarian to industrial societies with technology and information, related with people's demands and human resources.

Third, the challenge in the tightly increased global competition, related with how to improve the nation's competitiveness in improving the quality of the products, and able to compete as a result of mastery of science, technology and art (IPTEKS).

Fourth, the emergence of the new colonialism in the field of science, technology, and economy that replaces the political colonialism. Thus, colonialism is no longer physical, but in the form of information. The development of information technology commonly found in the form of computer and internet, which then makes Indonesia greatly dependent on the nations who have already mastered information technology. This is a new form of colonialism that has become a virtual enemy, which has entered all corners of the world.

This progress should be realized with a quality learning process and produce the graduates who are knowledgeable, professional, superior, visionary and have high confidence and self-esteem. In order to materialize this a proper and suitable strategy is needed. One of the strategies that can be done in developing the students' competence based on their ability, attitude, nature, and behavior so that students can enjoy the learning process.

The increased of students' competence cannot be seen pragmatically, apart from its whole parts. Instead, it must be seen through a systematic approach that is comprehensive, intact and not separated from the parts, so the progress reports on the rate of development of student towards the rate of students' competence can be seen as expected. Therefore, the role of educators in developing competitive spirits in adolescents needs serious attention to be studied in depth.

\section{METHOD}

The author uses literature review as the writing method and has analyzed several related kinds literatures comprehensively

\section{RESULT AND DISCUSSION}

Education is a process in which a nation prepares its young generation to fulfill the purpose of life effectively and efficiently. Education is also a process in which a nation or country fosters and develops the individuals' self-awareness. In this case, individuals refer to the young people who will continue the hard work of the previous generation.

The future of a nation lies in hands of the young generation. This is closely related to the optimism of Indonesians, who are very hopeful with the growth of the population in this country, especially the youth whose growth at this time developed so rapidly. It is even estimated that in 2045 they will make Indonesia a superior and advanced country. However, if this young generation is not getting a proper and well prepared, this thing will be a weakness for Indonesia itself. Therefore, the role of education becomes very important in preparing the young generation, so they can actualize The Gold of Indonesia in 2045. In actualizing all of those, an improvement in quality is necessary. Improving the quality of schools is not only limited to how good the school management is, but also how the students compete in achieving something good.

In conditions which differs from the essence of competition, a research conducted by [1] found that in developing adolescents' competition, especially in their studies 
which dealt university students' competitions, there are individual opportunistic factors and the need for preparedness system in developing students' competitive traits.

Motivating the students to see a competition as the essence of life that begins from the very early step of the human's creation, the competition of millions sperm to fertilize the egg, is not an easy task. This condition will continue after the humans born and become adults. In getting something that human desires, he/she must go through some competitions. Competitive (competition) is an activity in achieving goals by defeating other people or groups. Competence is characterized by a goal but no dependency. Competitive situation is characterized by a negative attitude in terms of dependence, where when someone wins, then the other loses [2]

Competing encourages students to expand their ability in dealing with the situation around them. The competitiveness of students will emerge as an effort to show their identity and abilities. Maximal achievement is something that is expected to be achieved in this learning situation. The students in this term refer to the adolescents. Before we begin to examine the factors that can bring a competitive spirit out, it will be better to learn first who these adolescents are.

Adolescence is a time of transition from childhood. This period is a period of instability. The development from childhood to adolescence passes through multiple lines. Human is an organism that is a biological being that will change or develop into individuals whose egoism will always grow. In this development, the role of parents and the environment in which the children grow will greatly affect their development of personality in the future. Individual behavior gradually becomes less and less sufficient until the development of selfawareness.

Hilgard explains that there are at least three important aspects that characterize adolescence: 1) The occurrence of physical changes (the development of hormones and sexual organs), 2) The existence of search and consolidation of identity, and 3) The existence of preparation to face the duties and responsibilities as an independent human. The phase of adolescence is often regarded as a very unstable phase in the stage of human development, where G.S. Hall calls it "strum and drang" or hurricane period, while James E.Gardner called it a period of turbulence (turbulent times). This assessment certainly based on the psychological and social reality of adolescents. In this adolescence phase, the process of maturation either physical or psychological occurs. In addition, teens also are demanded to be able to undergo their developmental tasks [3].

Havigrust in [4] defines developmental tasks as tasks that arise during or about a certain period of the individual's life. If one can successfully fulfill the tasks, it will lead to a happy phase and bring success in doing the next tasks. However, if one fails, it will cause unhappiness and difficulty in facing the next tasks.

The task of adolescent development is focused on improving childish attitudes and behaviors and attempted to attain mature behaviors. The following are the tasks of adolescent development according to [5].
1. Able to accept his physical condition;

2. Able to accept and understand the role of adult sex;

3. Able to foster good relationships with different group members;

4. Able to achieve emotional independence;

5. Able to achieve economic independence;

6. Able to develop intellectual concepts and skills indispensable for the role of community members;

7. Able to understand and internalize the values of adults and parents;

8. Able to develop the social responsibility behaviors necessary to enter the adult world;

9. Able to prepare them for marriage;

10. Able to understand and prepare the various responsibilities of family life.

Similarly [6] mentions the task of adolescent development as follows:

1. Able to socialize with peers of both sexes

2. Able to achieve social role as a man or woman

3. Able to accept their own physical state

4. Able to choose and prepare jobs

5. Able to choose a partner and prepare for a family

Based on that opinion, the writer concluded that the tasks of adolescent development are related to their attitude and behavior in responding to their surroundings. The changes that occur in physical and psychological demands the children to be able to adjust themselves to the environment and the challenges of life.

In order to help adolescents to undergo their developmental tasks, of course, educators such as parents, teachers, and adults around the adolescents must know the characteristics or characteristics of adolescent itself. This characteristic of adolescence has its own special characteristic since adolescence is a transitional period. Psychologically, adolescence is the age at which the individual integrates with the adult society and the age at which the child no longer feels below the level of the older people but is on the same level, at least in the issue of rights. Integration in the (adult) society has many effective aspects and the intellectual transformation of adolescent mindset makes it possible for them to integrate into adult social relations. Ref [5] divides the characteristics of adolescence more specifically, as follows:

1. Adolescence as an important period, because of physical and mental development and mental adjustment and the formation of attitudes, values and new interest occur in this period.

2. Adolescence as a period of transition, a change in attitude and behavior of children to adulthood.

3. Adolescence as a period of change, because there are five changes that are universal. i.e. Changes in emotions, body, interest and behavior patterns, and value.

4. Adolescence as a problematic age, because in childhood the problems are largely solved by teachers and parents so that most adolescents are less experienced in dealing with it.

5. Adolescence as a period of identity seeking, because adolescents try to explain who he/she is, and what role he/she has.

6. Adolescence as an age that creates fear, because of the cultural stereotype assumption that adolescents are children 
who are messy, cannot be trusted and tend to damage. This assumption is causing the adults to guide and supervise them.

7. Adolescence as an unrealistic period. Because teenagers see themselves and others as what they want to see, instead of seeing it realistically.

8. Adolescence as the threshold of adulthood, as adolescents, begin to focus on attitudes associated with adults [5].

During the adolescence phase, many problems will appear in the adolescents' life. These problems are among the most complex issues in the world. Starting from the problem of boyfriend/girlfriend, school problems, social problems, appearance problems and so forth. However, those problems are actually a process of identity search which will later become the beginning of maturity. In the search period of identity, every individual tries to find and ask for his identity.

The adolescents should look to themselves. In this age, they must learn and choose the correct ideology out of various ideologies that have been presented to them. In addition to the process of getting know themselves, the adolescence phase is also a process to know God. In adolescence, one can navigate the ladder of life easily and energetically, hence it is necessary to think before the act and deliberate. One should be a compassionate and broad-minded person so that he/she will not slip in this quest for identity. Because the adolescents who do not manage to find their identity well, in adulthood later will not reach full maturity. There are individuals who have grown up, but their behaviors are still childish. Not all adults behave based on a clear and rational principle of life.

Adolescence is a period where adolescents go through the process of searching identity; thus, at that time the adolescents are required to have confidence. The identity search period is a very important issue, and in this period it involves the role of many people

In short, the definition of identity is the real you. According to the psychology of children and adolescents of the Empathy Development Center, Roslina Verauli, "the identity of the self is actually the way a person sees himself, his identity is also known as self-concept." There are several broader definition, as follows:

1. Identity is the person that appears in a person naturally with a certain chronology.

2. Identity is a process of growth and development of positive values that emanate from the conscience through the heart.

3. Identity is a knowledge of who we really are.

4. Identity is the characteristic or image of a person who is seen from the soul and the motion from within.

Based on the definitions above, it can be concluded that identity is the inner expression of our place and our role in this world, to find the true meaning of life, as the guidance of life in finding true happiness in life [7].

Adolescents and identity are two things that are inseparable, but it is not rare for the adolescents to encounter obstacles in the process of seeking identity. The influence of negative peers can lead the adolescents to behave nonnormative, therefore the environment must be able to help the adolescents in finding their identity through a positive thing. One of the positive things is to develop their competitive spirit.
It is a sure thing that every parents and teacher want their students (adolescents) to have a high competitive spirit. The problem is, how to develop this trait and make the students get used to competing in a healthy way? The competitive spirit is a passion for achieving goals by defeating others or other groups. The spirit in competing for spur the students to explore their ability to deal with the situation around them.

This competitiveness will result in a willing for the students to do their best and show their ability they will achieve the best achievement. As educators, we certainly want our children to have high spirit in learning. This competitive spirit is very important for the students to have.

However, to cultivate a competitive spirit in students is not an easy work for the teacher. Different backgrounds of life, abilities, and character of students require the teacher to think before applying this competitive learning situation. There are several causes of the students' lack of will to explore themselves. Some of the factors are 1) feelings of shame, 2) reluctance to compete, 3) feelings of inferiority and 4) fear when doing something wrong [8].

To overcome the feelings of shame, we need to examine the factors that might cause it. There are many things that can cause this feeling - cultural factors are one of those. Cultural factors greatly affect the pattern of parents' education, which then will affect the formation of the child's character. It can also be caused by low self-esteem or humiliation when they are doing something that is not good and/or incorrect. The feelings of shame causes the students' confidence to be low. They will often feel uncomfortable in doing many things, especially something that is "seen by many people". In order to make them from that feeling, educators need to provide opportunities for the students to interact more with their friends. The lack of good intimacy can cause the occurrence of embarrassment, especially if they have to appear in a public place filled with strangers. Conducting a group learning or playing a game together can build a sense of familiarity among the children.

Commonly, many students are reluctant to compete. Therefore, their spirit of competing needs to be developed. Humans are formed from a single sperm cell among the millions of sperm cells that raced towards the egg, and only one is selected to be human. This indicates that humans have a nature to compete with each other. This state continues until the child is born. A competitive learning needs to be conducted by educators so that students have a competitive spirit, for example by conducting competitions in learning activities, holding quizzes, giving rewards for the most active students in answering questions, and many other ways.

Growing courage is one of the efforts to make the adolescents have a competitive spirit. Courage or selfconfidence can be grown by asking students to do tasks independently / individually, making presentations, conducting independent experiments, and giving students the opportunity to become the leader of a group.

Ref [9] concludes that the spirit of competition also needs to consider the degree of aggression and, of course, aggression is clearly different from growing courage. Similar to other efforts so to make the adolescents have no fear of failure, a 
high spirit in achieving their goal needs to be developed. The teachers need to give rewards to students who are doing well. The reward itself is a form of appreciation of an achievement that has been achieved by a person or group in a particular activity. Giving reward is a good thing to do, because it can encourage and motivate the students to do better. As the teachers, we need to be creative in designing a competitive learning. A teacher can build a competitive spirit by developping the spirit of innovation and creativity first [10].

\section{CONCLUSION}

Basically, a competitive learning is able to motivate students to explore their capabilities. This competitive spirit needs to be developed from an early age so that children are ready to face the competition that is so tight in the today's world. It also can train students to be more be wise in facing defeat and victory. Thus, when the child has a defeat or failure, he/she will be encouraged to be better, and when the child is victorious, he/she will not be arrogant but takes the winning as a factor of encouragement for them to achieve something better. By having a competitive spirit, the students have a spirit that is not easy to give up, tend to do hard work, diligent, focus and full concentration to succeed and not easily down in despair.

A competitive spirit can help us to achieve success both in academic, work and personal life. Competitive life is important for students because it is the essence of the competition itself. Having a good competing ability will result in a good achievement. Competitive learning can motivate students to actualize their abilities. This competitive spirit must always be developed within the students as an effort to prepare them for the real world.

Having a competitive spirit can have a positive impact on the life and future of the students. By having a competitive spirit, the students will be considered by others, they even can be a famous person and achieve much success in their life. However, the competitive spirit of the students must be well controlled, otherwise the people around them can feel the bad effects of that trait. Therefore, the role of teachers is very large to assist them in developing their competitive spirit without harming others.

\section{REFERENCES}

[1] Shao, Iris Yu Ting; Ng, Jhony Choon Yeong dan Yuan, Miaomiao.2016. "A Grounded Theory Research on China's College Student Entrepreneurship Competition." Reserachers World: Journal of Arts, Science \& Commerce. Vol.- VII, Issue - 4, Oktober: 88-95.

[2] http://myrestuwidi.blogspot.co.id/2015/01/menumbuhkan-jiwakompetitif-siswa.html [accessed on 19 March 2017].

[3] Santrock, John W. 2003. Remaja Jilid 1. Jakarta: Erlangga.

[4] Ali, Mohammad, et al. 2011. Psikologi Remaja-Perkembangan Peserta Didik, Jakarta: PT Bumi Aksara.

[5] Hurlock, E..B. 1993. Psikologi Perkembangan: Suatu Pendekatan Sepanjang Kehidupan. Jakarta. Penerbit Erlangga

[6] Zulkifli. 2005. Psikologi Perkembangan: Bandung PT Remaja Rosdakarya.

[7] http://dahliafridayanti.blogspot.co.id/2012/05/proses-pencarian-jati-diriremaja.html [accessed on 19 March 2017].

[8] http://tommyprakasa.blogspot.co.id/2011/10/membentuk-karakter-siswayang-kompeten.html [accessed on 19 March 2017].
[9] Eden, Sigal dan Alkalai, Yoram Eshet.2014.”The Effect of Digital Games and Game Strategies on Young Adolescents' Aggression." Journal Educational Computing Research, Vol. 50 (4): 449-466.

[10] B.A.,Ospanova, I.I., Sagdullaev dan A.E., Tashbulatova (2013). "AcmeCreative Self-Realization of The Student In The Educational Area of High School.” European Science and Technology October 3rd - 4th, Vol. II: $130-134$. 